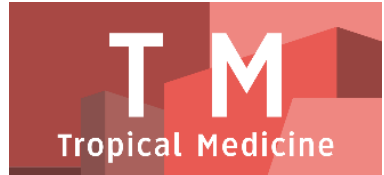

PAPER - OPEN ACCESS

\title{
Kualitas Hidup Pasien Hipertensi Tanpa Komplikasi di Daerah Puskesmas Medan Labuhan
}

\author{
Author $\quad$ : Arlinda Sari Wahyuni \\ DOI $\quad: 10.32734 /$ tm.v1i2.219 \\ Electronic ISSN : 2623-0550 \\ Print ISSN : 2623-0542
}

Volume 1 Issue 2 - 2018 TALENTA Conference Series: Tropical Medicine (TM)

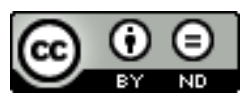

This work is licensed under a Creative Commons Attribution-NoDerivatives 4.0 International License.

Published under licence by TALENTA Publisher, Universitas Sumatera Utara
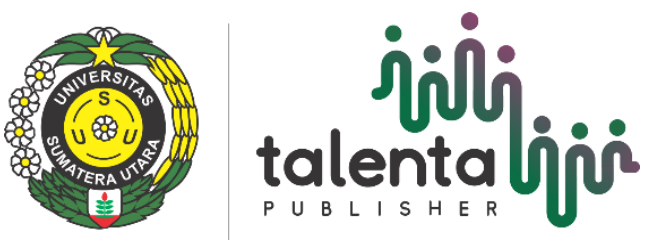


\title{
Kualitas Hidup Pasien Hipertensi Tanpa Komplikasi di Daerah Puskesmas Medan Labuhan
}

\author{
Arlinda Sari Wahyuni ${ }^{\mathrm{a}}$, Indah Royhan Lubis ${ }^{\mathrm{b}}$, Dara Novea Hutagalung ${ }^{\mathrm{b}}$, Hade Praja Hutasoit ${ }^{\mathrm{b}}$, \\ Robby Martin Simangunsong ${ }^{\mathrm{b}}$, Thamarai Somu ${ }^{\mathrm{b}}$, Rendy Giovani Sembiring ${ }^{\mathrm{b}}$, Nadiah Masyab ${ }^{\mathrm{b}}$, \\ Rahma Sari $^{\mathrm{b}}$, Divieya Tharisini ${ }^{\mathrm{b}}$, Nivarany Ananthan ${ }^{\mathrm{b}}$, Joyce Teo Jia Le ${ }^{\mathrm{b}}$, Chandra Meilyn \\ Manurunga ${ }^{\mathrm{a}}$ Bukhari Muslim Siregar ${ }^{\mathrm{b}}$ \\ ${ }^{a}$ Staf Pengajar Departemen Ilmu Kesehatan Masyarakat/Ilmu Kedokteran/Ilmu Kedokteran Pencegahan/Ilmu Kedokteran Komunitas, Fakultas \\ Kedokteran USU, Medan, Indonesia \\ ${ }^{b}$ Mahasiswa P3D Fakultas Kedokteran USU Angkatan 2012, Medan, Indonesia
}

dr_arlinda_123@yahoo.com

\begin{abstract}
Abstrak
Penyakit kardiovaskular akibat hipertensi dapat menyebabkan masalah pada kualitas hidup, sehingga kualitas hidup penderita akan terganggu dan angka harapan hidup juga akan menurun.Pengukuran kualitas hidup merupakan salah satu cara yang dapat membantu tenaga kesehatan dan masyarakat untuk mengetahui gambaran kondisi pasien, sehingga dapat melakukan pencegahan dan penanggulangan penyakit hipertensi dengan baik. Penelitian ini bersifat deskriptif dengan rancangan penelitian potong lintang. Populasi pada penelitian ini adalah penderita hipertensi tanpa komplikasi berusia $<60$ tahun yang memenuhi kriteria inklusi penelitian yaitu penderita hipertensi tanpa komplikasi berusia $<60$ tahun. Sampel penelitian dipilih dengan menggunakan teknik consecutif, yaitu sebanyak 84 . Hasil pengumpulan data didapatkan penderita hipertensi tanpa komplikasi berusia $<60$ tahun dengan skoring dari 8 komponen SF-36 dijumpai buruk. Dari komponen fungsi fisik dijumpai kualitas hidup buruk dengan persentase 38,16 , keterbatasan fisik 56,54, nyeri tubuh 58,17, kesehatan secara umum 52,07, vitalitas 48,0, keterbatasan emosional 50,39, dan kesehatan mental 49,67. Dari hasil penelitian ini, diharapkan pasien hipertensi dapat meningkatkan kualitas hidup dengan memanfaatkan fasilitas kesehatan, menambah pengetahuan mengenai kualitas hidup, dan mengikuti kegiatan promosi kesehatan sehingga penyakitnya dapat dikontrol.
\end{abstract}

Kata Kunci : Kualitas Hidup; Pasien; Hipertensi; SF 36; Medan Labuhan

\section{Pendahuluan}

Pada saat ini hipertensi adalah faktor risiko ketiga terbesar yang menyebabkan kematian dini. Kecenderungan berubahnya gaya hidup akibat urbanisasi, modernisasi dan globalisasi memunculkan sejumlah faktor resiko yang dapat meningkatkan angka kesakitan hipertensi. Merujuk pada angka prevalensi hipertensi yang terus meningkat setiap tahunnya, maka diperlukan suatu strategi yang dapat membantu petugas maupun masyarakat untuk dapat mengetahui sedini mungkin kecenderungan penyakit hipertensi[1].

Prevalensi kejadian hipertensi berkisar antara 5-35\% di berbagai negara di Asia sedangkan di daerah Asia Pasifik, prevalensi kejadiannya berkisar antara 5-47\% pada pria dan 7-38\% pada wanita. Berdasarkan data Riset Kesehatan 
Dasar (Riskesdas) Badan Penelitian dan Pengembangan Kesehatan (Balitbangkes), kejadian hipertensi di Indonesia secara nasional mencapai 31,7\% dan sekitar 26,3\% di daerah Sumatra Utara[2].

Berdasarkan profil Dinas Kesehatan Provinsi Sumatera Utara tahun 2008 yang merujuk hasil Riskesdas 2007 di Sumatera Utara, dari 10 jenis penyakit tidak menular diketahui bahwa prevalensi hipertensi menduduki peringkat tertinggi keempat dengan proporsi 5,8\% setelah persendian, jantung, dan gangguan mental[3]. Sedangkan berdasarkan penelitian Rasmaliah dkk di Wilayah Kerja Puskesmas Pekan Labuhan diketahui bahwa prevalensi hipertensi tekanan darah $\geqslant 130 \mathrm{mmHg}$ pada penduduk usia $\geqslant 26$ tahun sebesar 26,4\%[4]. Penderita hipertensi di Kota Medan cukup banyak.Penyakit ini sudah di peringkat kedua dari 10 penyakit terbesar di Kota Medan setelah penyakit ISPA (infeksi saluran pernafasan akut). Tahun 2012 ada sebanyak 46.736 warga Medan dideteksi menderita penyakit hipertensi yang terdiri dari 23.497 laki-laki dan 23.239 perempuan[3].

Menurut Gunawan, dampak dari penyakit hipertensi dapat memicu terjadinya resiko serangan jantung, stroke, dan gagal ginjal[5]. Sedangkan menurut Wade, tekanan darah yang terus meningkat mengakibatkan beban kerja jantung yang berlebihan sehingga memicu kerusakan pada pembuluh darah, gagal ginjal, jantung, kebutaan dan gangguan fungsi kognitif pada seseorang[6].

Studi yang dilakukan Degl'Innocenti menyatakan bahwa penyakit kardiovaskular akibat hipertensi dapat menyebabkan masalah pada kualitas hidup, sehingga kualitas hidup penderita akan terganggu dan angka harapan hidup juga akan menurun[7].

Proses kesehatan dan timbulnya penyakit itu berkaitan dengan status ekonomi, sosial-budaya, pengalaman dan gaya hidup pribadi [8]. Pengukuran kualitas hidup merupakan salah satu cara yang dapat membantu tenaga kesehatan dan masyarakat untuk mengetahui gambaran kondisi pasien, sehingga dapat melakukan pencegahan dan penanggulangan penyakit hipertensi dengan baik. Penelitian terdahulu menyebutkan bahwa pasien hipertensi memiliki kualitas hidup yang lebih rendah daripada subyek sehat. Untuk mengetahui dan mengukur kualitas hidup dari pasien hipertensi yang menjalani pengobatan dapat dilakukan dengan menggunakan kuesioner, dan paling sering digunakan adalah kuesioner SF 12 dan SF 36 [9]. Penelitian sebelumnya mengenai kualitas hidup pasien hipertensi dengan menggunakan skor utilitas menunjukkan bahwa pasien hipertensi dengan skor utilitas yang rendah menunjukkan tekanan darah yang lebih tinggi daripada pasien hipertensi dengan skor utilitas yang lebih tinggi[10].

Oleh karena itu, peneliti ingin melihat bagaimana gambaran kualitas hidup penderita hipertensi tanpa komplikasi di daerah Puskesmas Medan Labuhan.

\section{Metode}

Jenis penelitian ini adalah penelitian deskriptif, yaitu mengambarkan kualitas hidup pasien hipertensi tanpa komplikasi usia <60 tahun di Puskesmas Medan Labuhan. Penelitian ini menggunakan metode survei deskriptif dengan pendekatan cross-sectional (potong lintang). Penelitian dilakukan di Puskesmas Medan Labuhan di Kecamatan Medan Labuhan, Medan. Pengambilan dan pengumpulan data dilakukan selama 6 minggu, yaitu dari bulan Juni sampai dengan Juli.

Populasi dalam penelitian ini adalah penderita hipertensi tanpa komplikasi berusia <60 tahun yang berobat Puskesmas Medan Labuhan yang memenuhi kriteria inklusi penelitian. Kemudia besar sampel dihitung dengan menggunakan rumus deskriptif dan sampel yang didapatkan dari hasil perhitungan 84 orang.

Sampel penelitian dipilih dengan menggunakan teknik consecutive (consecutive sampling). Adapun kriteria inklusi penelitian ini adalah penderita hipertensi tanpa komplikasi berusia <60 tahun yang berobat di Puskesmas Medan Labuhan.

Data yang digunakan pada penelitian ini adalah kuesioner yang berisi beberapa pertanyaan yang terdiri dari 8 komponen penilaian yaitu Fungsi fisik, Keterbatasan Fisik, Nyeri Tubuh, Kesehatan secara umum, Vitalitas, Fungsi Sosial, Keterbatasan Emosional, dan Kesehatan Mental. Data kemudian diolah dengan menggunakan program komputer SPSS (Statistical Product and Service Solution) dan disajikan dalam bentuk tabel dengan perhitungan 
distribusi frekuensi sesuai dengan tujuan penelitian, yaitu untuk mengetahui gambaran kualitas hidup pasien hipertensi tanpa komplikasi usia $<60$ tahun.

\section{Hasil Dan Pembahasan}

Tabel 1 Karakteristik Responden Berdasarkan Jenis Kelamin, Usia, Agama, Pekerjaan, Pendapatan, Suku, dan Pendidikan

\begin{tabular}{|c|c|c|}
\hline Karakteristik & Jumlah & Persentase $(\%)$ \\
\hline \multicolumn{3}{|l|}{ Usia } \\
\hline 30-39 tahun & 6 & $7,1 \%$ \\
\hline 40-49 tahun & 23 & $27,4 \%$ \\
\hline 50-59 tahun & 55 & $65,5 \%$ \\
\hline \multicolumn{3}{|l|}{ Jenis Kelamin } \\
\hline Laki-Laki & 26 & $31 \%$ \\
\hline Perempuan & 58 & $69 \%$ \\
\hline \multicolumn{3}{|l|}{ Agama } \\
\hline Islam & 56 & $66,7 \%$ \\
\hline Kristen & 25 & $29,8 \%$ \\
\hline Buddha & 3 & $3,6 \%$ \\
\hline \multicolumn{3}{|l|}{ Pekerjaan } \\
\hline Ibu Rumah Tangga & 56 & $66,7 \%$ \\
\hline PNS & 7 & $8,3 \%$ \\
\hline Karyawan Swasta & 6 & $7,1 \%$ \\
\hline Wiraswasta & 11 & $13,1 \%$ \\
\hline Pensiunan & 4 & $4,8 \%$ \\
\hline \multicolumn{3}{|l|}{ Pendapatan } \\
\hline$<$ Rp700.000 & 10 & $11,9 \%$ \\
\hline Rp700.000-Rp1.000.000 & 34 & $40,5 \%$ \\
\hline$>$ Rp1.000.000 & 40 & $47,6 \%$ \\
\hline \multicolumn{3}{|l|}{ Suku } \\
\hline Batak & 29 & $34,5 \%$ \\
\hline Jawa & 31 & $36,9 \%$ \\
\hline Melayu & 17 & $20,2 \%$ \\
\hline Padang & 5 & $6,0 \%$ \\
\hline Lain-Lain & 2 & $2,4 \%$ \\
\hline \multicolumn{3}{|l|}{ Pendidikan } \\
\hline SD & 14 & $16,7 \%$ \\
\hline SMP & 35 & $41,7 \%$ \\
\hline SMA & 27 & $32,1 \%$ \\
\hline Sarjana & 8 & $9,5 \%$ \\
\hline
\end{tabular}


Penelitian ini dilakukan di wilayah kerja Puskesmas Medan Labuhan yang berlokasi di Jalan Hamparan Perak, Lingkungan VII, Kelurahan Martubung, Kecamatan Medan Labuhan, Kotamadya Medan, Provinsi Sumatera Utara, Indonesia.

Penelitian dilakukan pada 84 orang yang menderita hipertensi tanpa komplikasi usia $<60$ tahun yang bersedia mengikuti penelitian dan menjawab seluruh pertanyaan yang tertuang di dalam kuesioner.

Hasil penelitian pada tabel 1 dapat dilihat penyebaran responden berdasarkan jenis kelamin paling besar terdapat pada perempuan sebanyak 58 orang (69\%), sedangkan sebanyak 26 orang (31\%) responden adalah laki-laki. Berdasarkan agama, responden yang paling banyak adalah yangberagama Islam yaitu sebanyak 56 orang $(66,7 \%)$. Responden paling banyak berdasarkan pekerjaannya yaitu Ibu Rumah Tangga dengan jumlah 56 orang (66,7\%). Dari pendapatan keluarga per bulan dijumpai responden mayoritas dengan pendapatan keluarga per bulan $>$ Rp1.000.000 merupakan responden terbanyak yaitu sebanyak 40 orang (47,6\%). Responden berdasarkan suku paling banyak yaitu suku Jawa dengan jumlah 31 orang (36,9\%). Reponden berdasarkan pendidikan terakhir paling banyak yaitu , responden yang memiliki pendidikan terakhir SMPyaitu sebanyak 35 orang $(41,7 \%)$, sehingga mayoritas penderita hipertensi mempunyai tingkat pendidikan menengah kebawah.

Tabel 2 Rerata Nilai Skoring Kuesioner SF-36 pada Pasien Hipertensi

\begin{tabular}{lc}
\hline \multicolumn{1}{c}{ Dimensi SF-36 } & Rerata Nilai (mean) \\
\hline Fungsi fisik & 38,16 \\
Keterbatasan Fisik & 56,54 \\
Nyeri Tubuh & 58,17 \\
Kesehatan secara umum & 52,07 \\
Vitalitas & 48,05 \\
Fungsi Sosial & 55,85 \\
Keterbatasan Emosional & 50,39 \\
Kesehatan Mental & 49,67 \\
\hline
\end{tabular}

Pada tabel 2 mengenai skoring kualitas hidup pasien hipertensi dengan 8 komponen penilaian kuesioner SF-36 didapatkan kualitas hidup paling buruk dari faktor nyeri tubuh paling banyak dengan persentase 58,1 . fungsi fisik dengan persentase 38,16, keterbatasan fisik 56,54, kesehatan secara umum 52,07, vitalitas 48,0, keterbatasan emosional 50,39, dan kesehatan mental 49,67.

Tabel 3 Rerata Nilai Skoring Kuesioner SF-36 pada Pasien Hipertensi Tanpa Penyakit Penyerta

\begin{tabular}{lc}
\hline \multicolumn{1}{c}{ Dimensi SF-36 } & Rerata Nilai (mean) \\
\hline Fungsi fisik & 63,36 \\
Keterbatasan Fisik & 65,38 \\
Nyeri Tubuh & 54,47 \\
Kesehatan secara umum & 57,92 \\
Vitalitas & 61,31
\end{tabular}




$\begin{array}{lr}\text { Fungsi Sosial } & 53,20 \\ \text { Keterbatasan Emosional } & 58,19 \\ \text { Kesehatan Mental } & 59,09\end{array}$

Pada tabel 3 mengenai skoring kualitas hidup pasien hipertensi tanpa penyakit penyerta dengan 8 komponen penilaian kuesioner SF-36 didapatkan kualitas hidup paling buruk dari faktor nyeri tubuh paling banyak dengan persentase 54,47. fungsi fisik dengan persentase 63,36, keterbatasan fisik 65,38, kesehatan secara umum 57,92, vitalitas 61,31, fungsi sosial 53,20, keterbatasan emosional 58,19, dan kesehatan mental 59,09. Secara keseluruhan kualitas hidup pasien hipertensi tanpa penyakit penyerta umumnya cukup baik dengan persentase 59,11.

Penelitian sebelumnya mengenai kualitas hidup pada pasien lansia dengan hipertensi yang dilakukan di Puskesmas Gianyar I, Kecamatan Gianyar, Bali dijumpai responden memiliki kualitas hidup yang baik sama dengan kualitas jumlah pasien dengan kualitas hidup buruk dengan persentase 50\% dengan jumlah 29 orang dari 58 responden yang dilakukan pengambilan data. Responden lansia yang memiliki kualitas hidup yang buruk berdasarkan komponen kualitas kesehatan fisik lebih banyak dibandingkan dengan yang memiliki kualitas yang baik yaitu 36 orang (62.1\%)[11]. Sedangkan penelitian yang dilakukan di Puskesmas Rendang, Kabupaten Karangasem menunjukkan Kualitas hidup pada pasien hipertensi secara umum baik (58.3\%)[5], namun dari komponen kualitas kesehatan fisik buruk (71.7\%), kualitas psikologis baik (61.7\%), kualitas personal sosial tidak terlalu berpengaruh $(50.0 \%)$ dan kualitas lingkungan buruk (73.3\%)[5].

\begin{tabular}{lc} 
Tabel 4 Rerata Nilai Skoring Kuesioner SF-36 pada Pasien Hipertensi dengan Penyakit Penyerta Diabetes Melitus \\
\hline \multicolumn{1}{c}{ Dimensi SF-36 } & Rerata Nilai (mean) \\
\hline Fungsi fisik & 37,35 \\
Keterbatasan Fisik & 35,93 \\
Nyeri Tubuh & 34,54 \\
Kesehatan secara umum & 35,93 \\
Vitalitas & 39,06 \\
Fungsi Sosial & 31,46 \\
Keterbatasan Emosional & 44,80 \\
Kesehatan Mental & 41,45 \\
\hline
\end{tabular}

Pada tabel 4 mengenai skoring kualitas hidup pasien hipertensi dengan penyakit penyerta Diabetes Melitus dengan 8 komponen penilaian kuesioner SF-36 didapatkan kualitas hidup paling buruk dari faktor fungsi sosial yaitu 31,46, fungsi fisik dengan persentase 37,35, keterbatasan fisik 35,93, Nyeri tubuh 34,54, kesehatan secara umum 35,93, vitalitas 39,06, keterbatasan emosional 44,80, dan kesehatan mental 41,45. Secara keseluruhan kualitas hidup pasien hipertensi dengan penyakit penyerta diabetes melitus secara keseluruhan buruk dengan persentase 37,56.

Penelitian sebelumnya mengenai kualitas hidup pada pasien hipertensi dengan penyakit penyerta seperti diabetes melitus yang terkontrol dilakukan di RSUD Ratu Zalecha Martapura dijumpai kualitas hidup baik dengan 69,23 dan 
dari 8 komponen penilaian kualitas hidup berdasarkan SF-36, dijumpai 7 komponen dengan persentase yang baik yaitu di atas 60\%, namun jumlah sampel pada penelitian tersebut sedikit sehingga tidak dijadikan pembanding[13]. Sedangkan penelitian mengenai kualitas hidup dengan penyakit diabetes Melitus yang dilakukan di Kurdistan, Iraq terhadap 340 pasien hipertensi dengan penyakit penyerta diabetes melitus menunjukkan hasil yaitu kualitas hidup yang buruk dengan rerata 39,0\%[12], sehingga penelitian tersebut mendukung penelitian ini.

Pada penelitian ini, fokus perhatian pada pasien hipertensi dan didapatkan kualitas fisik dan lingkungan yang buruk. Kualitas fisik yang buruk dapat mempengaruhi kualitas kerja yang akan memberi pengaruh pada kemampuan untuk memenuhi kebutuhan sehari- hari[14]. Berdasarkan segi kualitas lingkungan, penyakit yang diderita dapat menimbulkan beban finansial yang lebih apalagi jika lansia tidak memiliki jaminan kesehatan, hal ini akan menjadi beban dan secara tidak langsung mempengaruhi kemampuan penderita hipertensi dalam pemenuhan kebutuhan yang lain. Kualitas lingkungan juga dipengaruhi oleh ketersediaan informasi, sarana kesehatan dan lingkungan rumah yang bersih dan memadai[15]. Ketersediaan informasi dapat diperoleh dari penyuluhan yang sebaiknya diadakan secara rutin. Sarana kesehatan dan akses yang mudah untuk dijangkau membuat pasien dengan mudah untuk mengontrol penyakitnya sehingga secara tidak langsung mempengaruhi kualitas fisik dan psikologis.

\section{Hasil Dan Pembahasan}

Gambaran kualitas hidup pasien hipertensi usia <60 tahun di daerah sekitar Puskesmas Medan Labuhan sebagian besar buruk dengan persentase dari 8 komponen skoring dari SF-36 <50. Dari 8 komponen penilaian berdasarkan skoring kuesioner SF-36 dijumpai kualitas hidup paling rendah dari fungsi fisik dengan persentase 38,16 dan kualitas hidup paling baik dari faktor nyeri tubuh dengan persentase 58,17.

Dari seluruh proses dalam menyelesaikan penelitian ini, maka dapat diungkapkan beberapa saran yang mungkin dapat bermanfaat bagi semua pihak yang berpern dalam penelitian ini. Adapun saran tersebut, yaitu mengambil sampel yang lebih banyak, melakukan metode wawancara langsung ditempat agar sampel tidak bias. Selain itu, peneliti menyarankan kepada peneliti lain dapat mengembangkan penelitian mengenai gambaran kualitas hidup pasien hipertensi dengan responden dan lokasi penelitian yang lebih besar lagi.

\section{Referensi}

[1] Departemen Kesehatan RI, Masalah Hipertensi di Indonesia, 2010.

[2] Departemen Kesehatan. Riset Kesehatan Dasar. Jakarta: Badan Penelitian dan pengembangan Kesehatan Kementrian Kesehatan RI 2007.

[3] Profil Dinas Kesehatan Sumatera Utara 2012

[4] Rahajeng E, Tuminah S. 2009 Prevalensi Hipertensi dan Determinannya di Indonesia. Jakarta: Pusat Penelitian Biomedis dan Farmasi Badan Penelitian Kesehatan Departemen Kesehatan RI, Jakarta.

[5] Gunawan, Lany. 2001. Hipertensi (Tekanan Darah Tinggi), Yogyakarta : Kanisius Fogari dan Zoppi. Journal effect antihypertensive agents on Quality Of Life in the Elderly.

[6] Yogiantoro, M. 2009 Hipertensi Esensial. In: Sudoyo, A.W., et al eds. Buku Ajar Ilmu Penyakit Dalam 5th ed. Jilid II. Jakarta: Interna Publishing 2009, 1079-1085.

[7] Degl' Innocenti A. 2002 Journal. Cognitive Function and Health-Related Quality of Life in Elderly Patients with Hypertension-Baseline Data from the Study on Cognition the Elderly (SCOPE). Francis.

[8] Anggara Dwi, FH dan Prayitno N. Faktor-faktor yang Berhubungan dengan Tekanan Darah di Puskesmas Telaga Murni Cikarang Barat 2013. Jakarta: Program Studi Kesehatan Masyarakat STIKES MH. Thamrin. Jurnal Ilmiah Kesehatan. Vol 5 No. 1

[9] Trevisol DJ, Moreira LB, Kerkhoff A, Fuchs SC, Fuchs FD.2011 Health-related quality of life and hypertension: a systematic review and meta-analysis of observational studies, J Hypertens.29(2):179-88

[10] Stein DJ, Brown GC, Brown, MMSharma S, Hollands H, Stein HD. 2002 The Quality of Life of Patients With Hypertension, J Clin Hypertens. 4; 181-188

[11] Castro S.M de Oliveira, Coutinho R.M.2011. Quality of life of patients with hypertension. Journal of School Nursing, University Paulista, Campinas-SP. Brazil. 
[12] Poljičanin, T, Ajduković, D, Šekerija, M, Okanović, MP, Metelko, Z, Mavrinac, GP. 2010 DiabetesMellitus and Hypertension have Comparable Adverse Effects on Health-related Quality of Life. BMC Public Health.10(12): 1-6.

[13] Khaw, WF, Hassan, STS, dan Latiffah, AL. 2011 Health-related Quality of Life Among Hypertensive Patients Compered with General Population Norms. J. Med. Sci.11 (2): 84-89.

[14] Theodorou. 2011 Quality of life measurement in patients with hypertension in Cyprus.Hellenic journal of cardiology : 52

[15] Jiang, L, Beals, J, Whitesell, NR, Roubideaux, Y, Manson, SM. 2009 Health-Related Quality of Life And Help Seeking Among American Indians With Diabetes And Hypertension. Qual Life Res.18: 709-718. 